
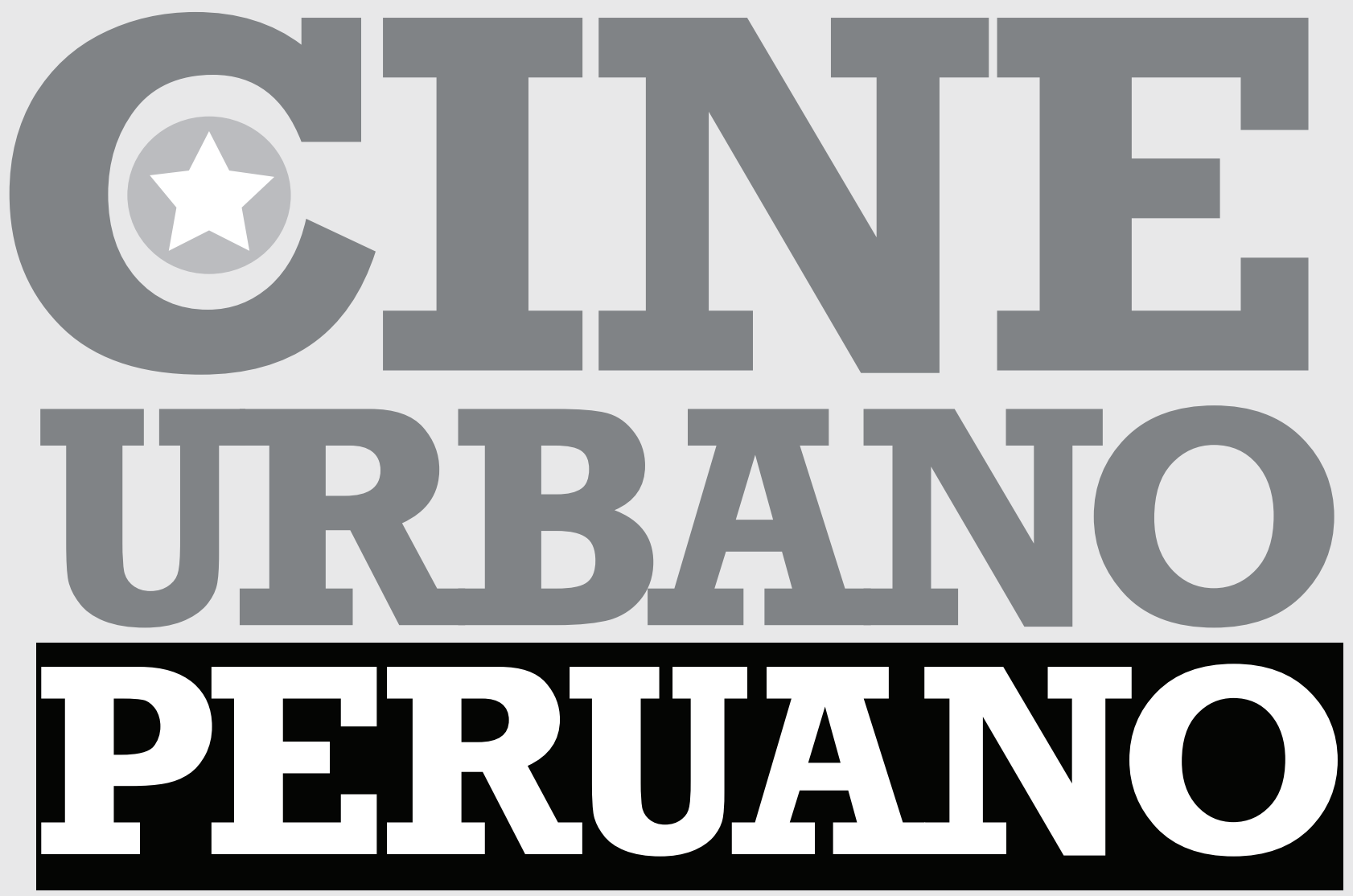

\title{
Lo bueno, lo malo y lo feo
}

En Lima, como en otras ciudades de la costa, sobre todo a partir de la década pasada, se han realizado películas sin ningún apoyo económico del Conacine y con presupuestos a veces casi inexistentes. Ventana Indiscreta ha hecho una selección de estas cintas para apreciar sus rasgos estilísticos más saltantes.
La farándula (Cristian Cancho, 1998)

Este filme es uno de los antecedentes de las numerosas películas hechas en video, y de manera autofinanciada, en la Lima de los últimos años. La farándula es una cinta protagonizada por numerosos juguetes, sobre todo de la colección Barbie.

Las 'barbies' de La farándula ponen en escena un inventario de perversiones de manera hilarante, fresca y lúdica. El director, Cristian Cancho, hereda los arquetipos, narrativas, trucos y la estética que privilegia los acabados toscos de las películas serie B y del softcore de los años ochenta. Sin embargo, La farándula, que se vale del stop motion para dotar de movimiento a los muñecos, no es un ejercicio de copia de estos recursos; se trata, más bien, de repensarlos. No se trata del homenaje hecho por el alumno más aplicado de la clase, sino del realizado por el estudiante cuyas pulsiones activan su imaginación. 
Los créditos iniciales, con su atmósfera de película casera, y sus primeras imágenes -en las que la cámara se acerca al interior de una tribu de muñecos caníbales que se comunican mediante un lenguaje inventado y grotesco-, es la primera advertencia sobre los fetiches que definirán a La farándula. Esta es una película sobre los rituales de grupos cerrados. Conciertos,

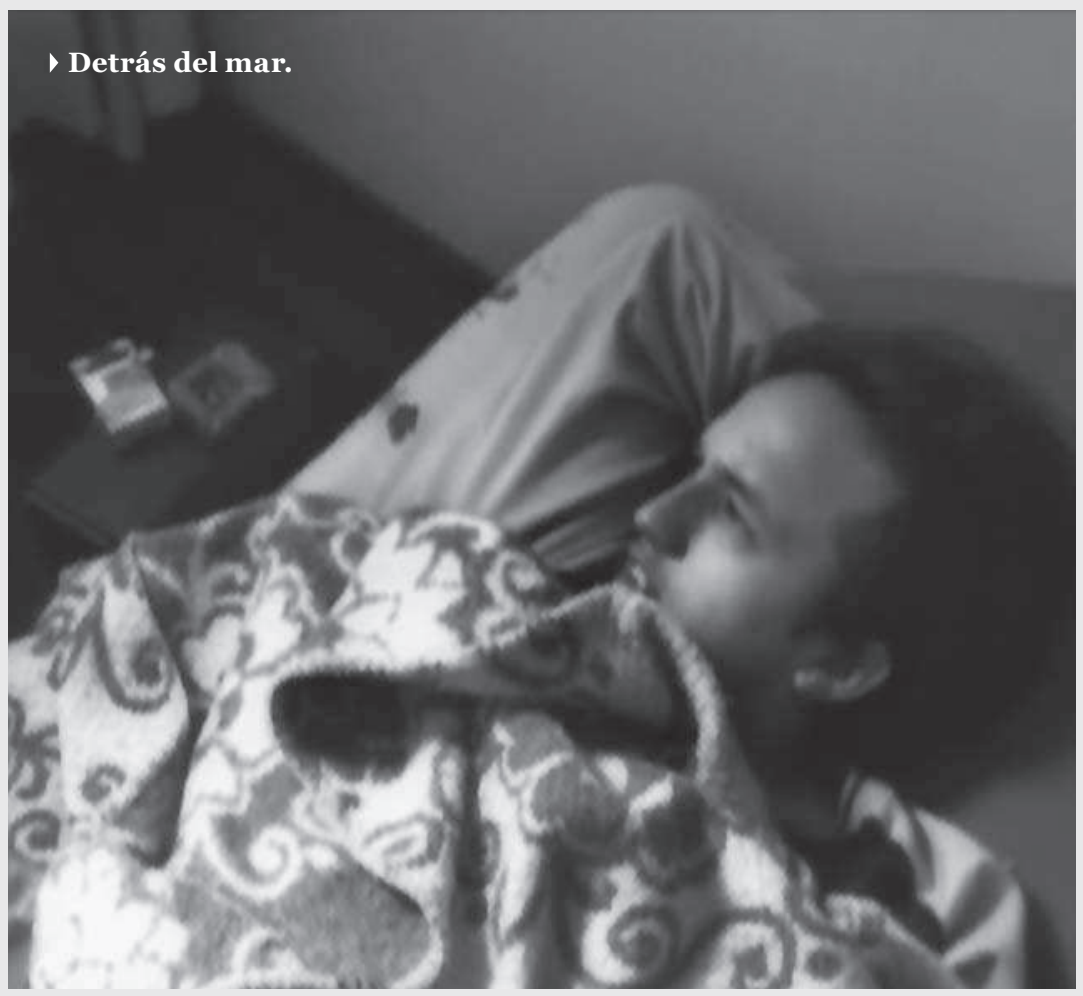

sacrificios humanos y orgías guardan asombrosas coincidencias: los caníbales, los músicos, las chicas descerebradas y los chicos millonarios parecen tener solo un mecanismo de comunicación, el sexo; lo demás es ruido de fondo.

La transgresión en La farándula está presente en diferentes niveles. Casi todos los personajes parecen sufrir de síndrome de Tourette, pero la enfermedad no es sinónimo de deterioro. El lenguaje de los muñecos está marcado por un vocabulario limitado, aunque útil y gráfico para describir imágenes sexuales. Los rasgos etéreos de los cuerpos de Ken y Barbie son trastocados en el montaje a partir de prótesis monstruosas y vello púbico abundante. Dichas prótesis cumplen un papel protagónico, porque el hilo conductor de La farándula, que es el sexo, se cimenta sobre la genitalidad.

Los personajes de La farándula no están guiados por el deseo, sino por sus genitales. La película se encarga de separar bien ambas dimensiones. Los órganos sexuales son la puerta de entrada para introducirnos a insospechadas criaturas, como aquel caballo que es

\section{elevado a la categoría de símbolo} sexual por las amigas de Barbie, o como aquella improvisada versión del Jason de Viernes 13, quien abandona el cementerio con el objetivo de vengarse de quien orinó en su tumba.

La farándula no ejerce juicios morales sobre sus personajes: los pederastas, los zoofilicos, los homosexuales y los violadores no son héroes ni villanos, están al margen, siempre son bufones.

Quiñonez Salpietro

\section{Detrás del mar (Raúl del Busto, 2005)}

La ópera prima de Raúl del Busto ha sido catalogada como uno de los ejercicios cinematográficos más interesantes del reciente cine peruano. Sin duda, lo es, pero sus defectos y virtudes radican en esa misma afirmación. Detrás del mar funciona como una propuesta osada y distinta, más aún dentro de nuestro escaso cine nacional, pero falla por ser precisamente no más que un valiente ejercicio de cine minimalista.

El minimalismo está presente en los planos largos, contemplativos, en sus personajes, que no usan la palabra sino que hablan con sus acciones cotidianas; en sus historias y pasados desconocidos, en el ambiente que respira silencio y hermetismo. Es valiente filmar un largometraje de personajes sin aparente historia, que son sombras de lo que parece ser un secreto que guarda solo el mar, así como es valioso rodar una historia donde recién al último minuto escuchamos la voz de un personaje, del cual no sabemos ni su nombre, como sucede con los otros dos. En tal sentido, la cinta es explícitamente conceptual: muchas de las ideas de Del Busto quedan en su cabeza, y por tal razón, cualquier espectador puede especular, crear o completar la ficción.

Pero lo valiente no quita el tedio y las fallas en las que cae recurrentemente la película. Hay muchos ejemplos de películas lacónicas donde terminamos compenetrándonos con los personajes (Detrás de los olivos o La ciénaga, por dar dos ejemplos de latitudes distintas), pero aquí no solo no llegamos a comprender qué sucede con ellos -claro propósito de su autor-, sino que nunca llegamos siquiera a interesarnos por ellos. Sus acciones son tan intrascendentes en muchos de los casos que no llaman en absoluto nuestra atención. Queda claro que ese es el código que maneja Del Busto, pero aun así es inevitable sentir el aburrimiento una hora y media después de lo mismo. En este caso, el director se hubiese podido valer de la estética para de alguna manera equilibrar aquella desdramatización en su película, para que así invite a leer al detalle cada encuadre, cada componente de la fotografía y cada sonido en medio del silencio. Pero en ese aspecto se 
resaltan las fallas de un trabajo cinematográfico aún principiante, donde apreciamos una mala edición del sonido ambiental, una fotografía que por momentos es interesante por su desaturación del color, pero que en otros solo llega a mostrar la poca calidad del digital. Se nota que hay una mano, un pulso en la dirección, una búsqueda formal, pero esas fallas terminan por menoscabar la intención de Del Busto.

Detrás del mar representa una mirada personal en nuestro cine, una mirada quizá independiente, sí, pero más en un sentido simbólico que real. Raúl del Busto ha hecho de su ópera prima un importante aporte a un cine más alternativo, y aunque puede ser solo un ejercicio de estilo con defectos y virtudes, vale la pena ser visto.

Medina

\section{Los actores (Omar Forero, 2006)}

La ópera prima del trujillano Omar Forero es un referente de lo que algunos llaman "cine independiente peruano". Es una de las obras más singulares de la producción regional, que mayoritariamente se ha inclinado por historias terroríficas, sobrenaturales, melodramáticas o tributarias de una tradición ancestral.

En cambio aquí la mirada es minimalista, y está enfocada en la periferia urbana, en seres que en primera instancia se muestran discretos, retraídos y lacónicos. Con la cámara quieta que coloca en diferentes ángulos, definiendo las locaciones y situaciones con escasas imágenes, por lo general planos secuencia, Forero busca registrar los "momentos" que se producen inercialmente en una cotidianidad no exenta de altibajos $\mathrm{y}$ tensiones, pero que pasan por el filtro de

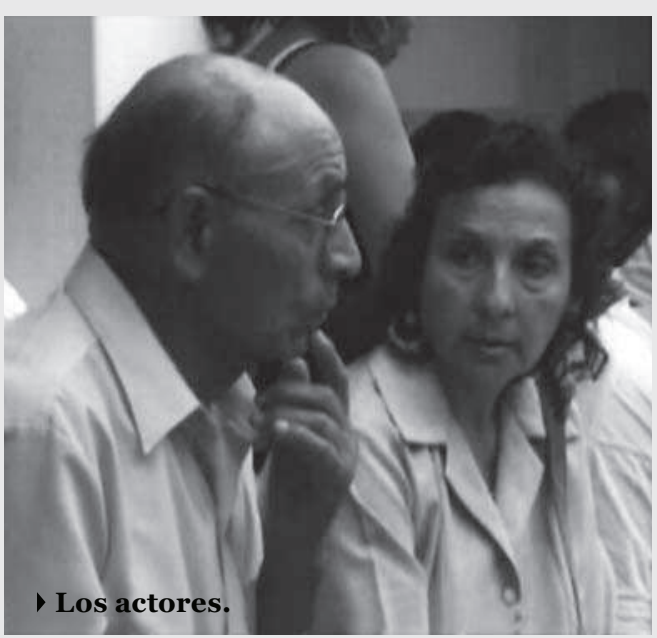

la desdramatización, entre la comunicación tímida y casi silenciosa de los jóvenes, incluido el flirteo adolescente, y la explosión de histrionismo o histeria de personajes maduros, que incluyen invectivas y órdenes.

Los actores funciona así como una suerte de análisis clínico del comportamiento en un entorno popular, un mosaico de cómo las personas, en interacción con la colectividad, construyen en diferentes "registros" su expresión personal. El relato juega a contraponer esta a una entusiasta vocación escénica, que en el caso de la joven pareja encuentra en el ensayo teatral un guiño pícaro a su relación, que transita desde sus primeros acercamientos a una convicción íntima cada vez mayor-aunque siempre lejos de la euforia- y que llega a desafiar subrepticiamente la intolerante presencia materna.

Asimismo, este espejismo se manifiesta en el hombre maduro que mantiene el perfil bajo en casa, en verticales discusiones con su esposa autoritaria, pero que sobreactúa y se contorsiona ante el generoso auditorio de un colegio y es capaz de 'marketearse' en una cabina
"Los actores funciona así como una suerte de análisis clínico del comportamiento en un entorno popular, un mosaico de cómo las personas, en interacción con la colectividad, construyen en diferentes 'registros' su
expresión personal'. radial y luego agradecer por la (auto)invitación. Es decir, en la película quienes tienen interés en "actuar" curiosamente son agredidos por individuos de interpretación tosca, lapidaria y anticarismática, y marca el ritmo narrativo de Forero, áspero en la contemplación.

Quispe

\section{Alienados (Rafael Arévalo, 2008)}

El primer largometraje de Rafael Arévalo presenta o, más bien, trata de afilar una propuesta relativamente reciente en el panorama de la realización actual en el Perú. Es un relato que se pretende atípico y austero. Arévalo es un director bastante interesado en la estilización, pero también en lo estrambótico, hasta el punto de que eso lo ayuda a superar algunas evidentes barreras propias del cine guerrillero, aquel que practican muchos jóvenes en nuestro país, como 
las deficiencias actorales o las de otra índole derivadas de ese nivel de producción.

Alienados cuenta una historia de ciencia ficción, de suspenso, casi alegórica sobre el mundo juvenil pero traspasada por la abstracción. Blanco y negro, locaciones mínimas e interpretaciones lacónicas componen sus imágenes durante una hora y cuarenta minutos. En ellas se narra una incierta intriga derivada del horror más clásico, el de las grandes y veladas conspiraciones, aunque su opción sea también rozar lo autoral, remitir al expresionismo o a las claves propias del cine experimental, con evidente entusiasmo.

Designados sus personajes con apelativos astrales y sometidos a una influencia más allá de la luna, Arévalo se muestra como un atento observador del cine como herramienta de escape de la mera verosimilitud, aunque ese entusiasmo no oculte la apariencia de obra casi estudiantil que su película posee. "Aunque Sinmute $\begin{aligned} & \text { Aquellos tópicos que bien } \\ & \text { pueden funcionar como }\end{aligned}$ tiene momentos corto, son los que intenta emplear modestamente intensos (la en un lánguido y extenaparición repentina del payaso, o visión de unos sujetos que miran como autómatas unos viejos televisores), como conjunto, resulta poco sólida". dido ritual de "contacto" con fuerzas alienígenas. Aunque la idea es interesante, la del grupo de amigos en busca de lo extraordinario pero afectados por un extravío de la identidad propia o generacional, esta se agota en esas resoluciones reiterativas, incluso hasta lo que podría identificarse como el clímax de una narración carente de esas revelaciones o momentos epifánicos, un poco como los del asombro en medio de la cotidianidad planteada por Aki Kaurismaki en sus películas, autor que también debe de estar muy presente en las inclinaciones de Arévalo.

A los alienados de la cinta también se les quiere hacer seguir esa línea o actualización del rol de "modelos" a lo Bresson, pero la idea no deja de lucir como un esbozo, como un asomo de prototipo. Temas de intereses quedan planteados en esta primera obra y sin duda quedarán motivos para ver qué se traerá Arévalo después. Aun así, queda como muestra el vagabundeo, los temores al futuro, y los sonidos post rock como muestra de que estos chicos están tan emparen-

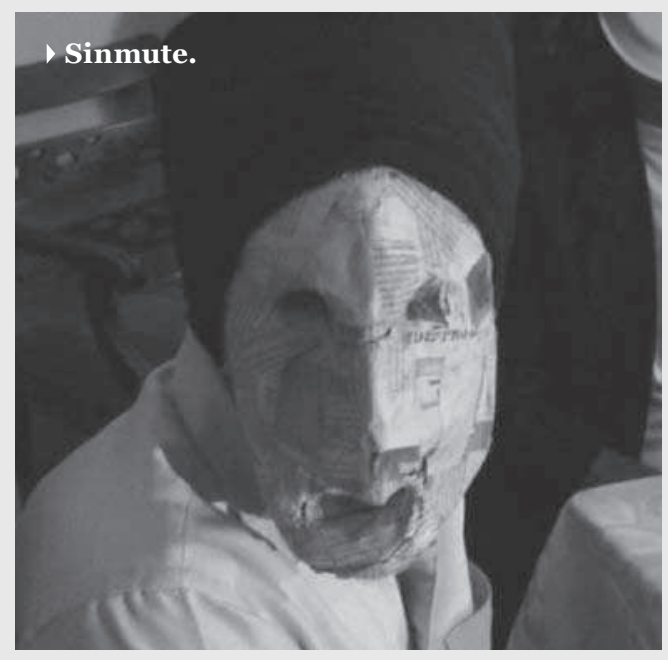

tados en su extrañeza a varios otros de nuestro sufrido cigoto cinematográfico.

Esponda

\section{Sinmute (Javier Bellido y Ana Balcázar, 2008)}

Un personaje nublado por el tedio de la civilización, atraviesa como una máquina la ciudad, impersonal y deshumanizada, donde las relaciones están llenas de caretas y prejuicios. Incluso dentro de una representación familiar, se asumen roles de felicidad y bienestar, aunque tengan como cena una repulsiva cabeza de cerdo.

Hay una tendencia a huir de aquella pesadilla, de la humanidad enferma e hipnotizada por los medios, la rutina y las apariencias. Por momentos, Sinmute se hunde en los demonios del protagonista llevándolo a una especie de abandono. Pero también se rebela; así, vemos a un payaso obsceno que destruye violentamente la cabeza de chancho que antes fue la falsa abundancia de la mesa. Él y un espantapájaros monstruoso, nos hacen pensar si es que acaso la rebelión es uno de los grandes miedos de nuestros tiempos.

En la película no hay intento de contar una historia, sino la necesidad de trasmitir esas inquietudes y conflictos. Aunque Sinmute tiene momentos intensos (la aparición repentina del payaso, o visión de unos sujetos que miran como autómatas unos viejos televisores), como conjunto, resulta poco sólida. En general, la edición discontinua de la película se desarrolla sin lograr una atmósfera poderosa que recorra sus imágenes inconexas. Está muy lejos de conseguir siquiera algo parecido a lo que encontramos en un clásico como El perro andaluz, que, a través de sus imágenes, carentes de un vínculo coherente entre sí y montadas a la 
manera de una sucesión onírica, está dotada de una energía, una fuerza, una pulsión tan humana como animal.

Sinmute no consigue enlazar sus visiones de sueño con convicción y se pierde en el intento. Por ello, el personaje central, aquel que deambula por calles vacías, es una buena metáfora de lo que ocurre en la película: es un joven de apariencia arty/indie que no sabe a dónde va.

Núñez Mas

\section{3 (Eduardo Quispe y Jim Marcelo, 2010)}

Destinos inciertos, Lima fúnebre y diálogos filmados en "estado natural” es lo que nos presentan Eduardo Quispe y Jim Marcelo. 3 es parte de una serie de películas realizadas por ellos y que llevan justamente números como nombres. En la película 1 vemos el inicio de una pareja destinada a un final prematuro. Él y ella, melancólicos y desolados, son incapaces de conectarse con el exterior para establecer un lazo afectivo. Las cintas 2 y 4 nos sumergen en la fijación hacia una chica, que se torna en desencanto y con una cámara se adentra en los vaivenes de la cotidianidad, lo que origina un quiebre entre la historia inicial y los episodios que se van entretejiendo.

Una cámara inquieta recorre un parque en 3. El eco del viento, los carros pasando, los perros ladrando apaciguan las palabras que se quiebran y se entremezclan con el silencio.

Quispe y Marcelo emplean la austeridad narrativa, el ritmo distendido, la dilatación en los encuadres. Pero es en 3, a diferencia de las otras, donde hay un mejor manejo del retrato llamado "naturalista". A partir de un gran plano secuencia, el lente deambula por un parque donde se suscitan una serie de conversaciones: una mujer que expone sus inseguridades sobre cómo manejar las prioridades en su intimidad, una pareja que discute acerca de la posesión y el control en su relación, dos desconocidos sentados a los extremos de una banca envueltos en un silencio inquietante, dos seres compartiendo sus experiencias, y una mujer esperando acaso lo inesperado, son los elegidos para retratar una noche cualquiera.

Los diálogos no son ostentosos, sino sobrios, sencillos y de lo más naturales. Hay una mejor fluidez que en sus predecesoras. El problema radica en la falta de claridad del sonido que, en diversos momentos, los perjudica.

1, 2, 3 y 4 transitan en el sentido de una no pertenencia, de una incertidumbre y desesperanza. Son muestra de un cine espontáneo de jóvenes perdidos y solitarios, que tiene como fondo una Lima gris, que, al igual que sus personajes, parece desolada

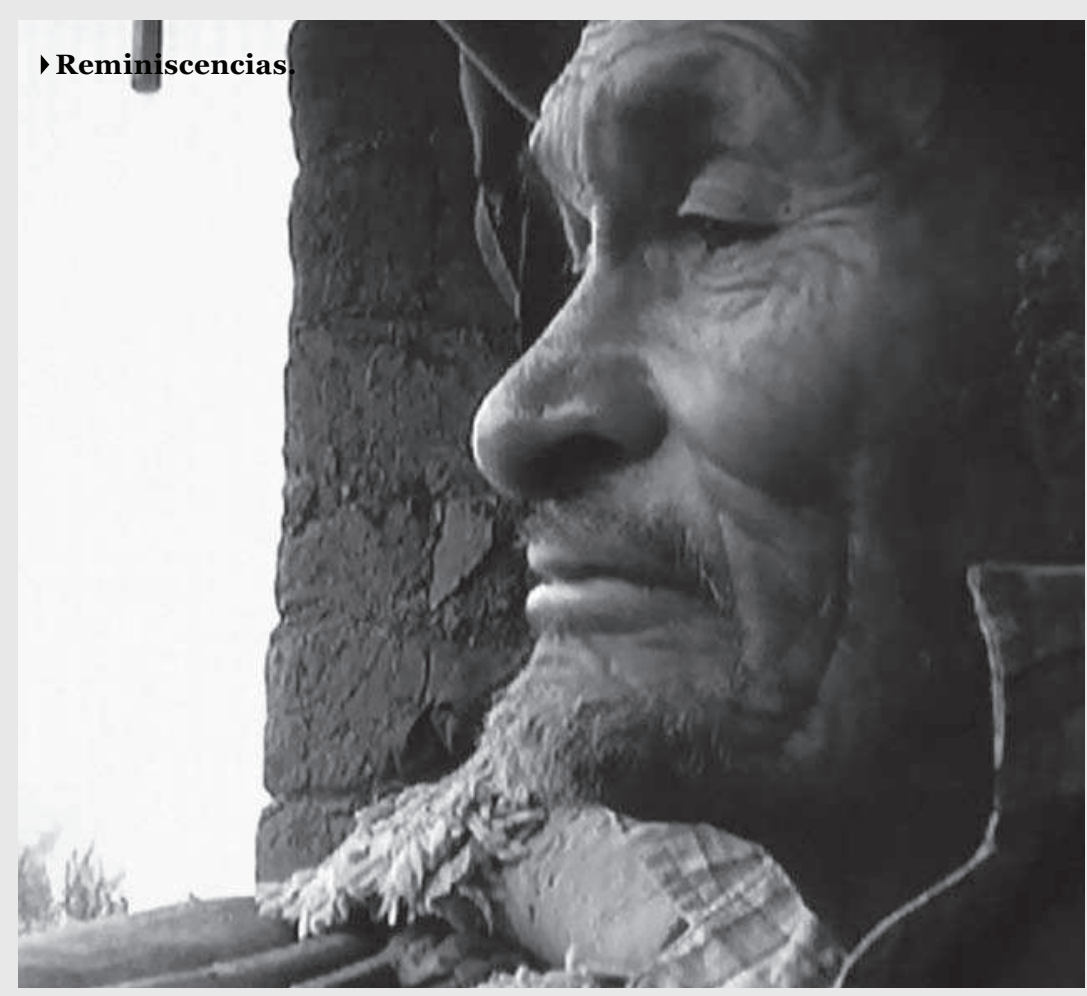

y atípica. Ellos tratan de sobrevivir a otro día más, a la falta de sentido en sus vidas, mediante la conexión con otro ser en sus mismas condiciones. Como dice el viejo dicho, la miseria busca compañía.

Sobrevilla

\section{Reminiscencias (Juan Daniel Fernández, 2011)}

Luego de ver Reminiscencias (2011), primer largo de Juan Daniel Fernández, de inmediato pensé en
Tarnation (2003), de Jonathan Caouette. Ambos son documentales que recuperan la vida y el archivo de su autor, ambos contienen una fuerte carga emotiva en la medida en que encarnan proyectos vitales (de toda la vida y que involucran la existencia de su autor en tanto que la recrean), ambos responden a una necesidad de revisión y exploración personal. Se trata de documentales que giran sobre sí mismos: su tema es su existencia y reflexionan en su discurrir sobre su propio proceso creativo. Hasta aquí son proyectos similares.

Reminiscencias se estructura alrededor de la idea de la reconstrucción de un pasado perdido. Vemos 
$\mathrm{Y}$ entonces empiezan las diferencias. La premisa de Tarnation es más simple: solo contar la vida del autor con ese archivo recopilado a lo largo de la existencia. Ocurre que la vida de Cauoette resulta impresionante por sí misma: a los once años interpretaba a mujeres golpeadas frente a "Cada viernes una cámara por pasatiempo, o está la trágica historia del desequilibrio mental de sangre se edifica

a partir de su madre. Son imágenes muy fuertes, su vida ya le había dado el insumo para un gran relato. Es decir, una marcada estilización en exageremos y digamos que con un excelente montaje ya tenía todo.

la que los datos referenciales están constantemente minados".

Reminiscencias, en cambio, requiere del mecanismo de la amnesia. Sus imágenes por sí mismas son cotidianas. Si bien el autor emprende una suerte de búsqueda de sus orígenes, siguiendo el rastro de algunos familiares, de no conocer el espectador el motivo que lo impulsa, su pesquisa y el abigarrado recuento de su vida se desvirtuarían. Reminiscencias construye un juego de espejos fuera de lo filmado y en eso reside su valor conceptual. La pregunta, entonces, sería si también se trata de un valor cinematográfico.

Eugenio Vidal

\section{Cada viernes sangre (Fernando Montenegro, 2011)}

El segundo largo de Fernando Montenegro parece ser una historia criminal, pero no es solo una historia criminal. O, mejor, es una suerte de simulación de historia criminal. Por lo pronto, la referencia inicial sobre los hechos reales en los que se inspiraría el relato es una pista equívoca, pues lo que vamos a ver luego es, prácticamente, la negación de cualquier atadura realista.

Cada viernes sangre se edifica a partir de una marcada estilización en la que los datos referenciales están constantemente minados. Uno de ellos es la cronología que se inicia un jueves 13 para seguir progresivamente hasta el viernes 7 y de allí saltar hasta el viernes 14. La sangre del viernes 13 es mínima, a diferencia de la que se derrama el viernes 14 , pero eso no es significativo, sino una parte de los mecanismos de enmascaramiento que se aplican. Enmascaramiento que se expresa de manera obvia en la máscara que utiliza el personaje de Chris para cometer los crímenes, pero también en los subterfugios de los que se valen los personajes para convencer a los otros a realizar, principalmente, acciones criminales. También en los desplazamientos y transferencias muy sutiles que se presentan en los personajes, y de manera particular en los femeninos. Enmascaramiento, finalmente, de Denisse (Claudia Burga), la protagonista, que termina eliminando a Chris, el objeto de amor-deseo, al que se somete en sesiones eróticas sadomasoquistas.

El enmascaramiento se extiende a los procedimientos audiovisuales: picados y contrapicados en gran angular, inclinaciones del encuadre, cambios cromáticos, intermediaciones de objetos en planos en que dialogan dos personajes, súbitos pasos de una situación a otra... Así, la historia criminal aparece algo "disuelta" porque no existe la tensión propia de un relato criminal canónico y porque hay un nivel oculto, pasional y extraño, que está agazapado y que moviliza a esos personajes finalmente indescifrables y en el centro de ellos a esa peculiar abeja reina que encarna Claudia Burga.

Cada viernes sangre es una aproximación manierista a la puesta en escena fílmica, que tiene a su favor una cuota de irreverencia genérica, de libertad para afrontar el relato, pero que también posee por ratos un cierto mecanicismo que pone en evidencia esa voluntad transgresora, sin que los diversos componentes de la puesta en escena estén a la altura de las exigencias; por ejemplo, la dirección de actores, que ofrece debilidades; o la misma construcción del guion que, sin perder la tónica aleatoria que posee el filme, pudo aportarle un poco más de "presencia y permanencia” a algunos personajes apenas delineados en la hora de duración del filme.

León

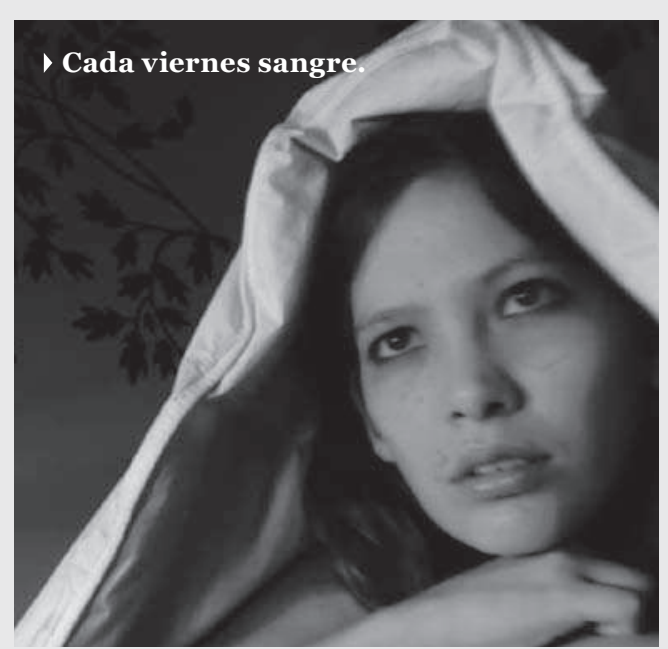

